\title{
Systems of Values of the Young People: Comparative Analysis of a Research in China and Kazakhstan
}

\author{
Svetlana Mikhailovna Puzikova
}

\author{
Doctor of Pedagogical Sciences, Assistant Professor of Sociology \\ Professor of General and Ethnic Pedagogy of Al-Farabi Kazakh National University
}

Mikhail Fedorovich Puzikov

Doctor of Historical Sciences, Professor of Sociology and Social Work of Al-Farabi Kazakh National University Addressee's Post Code: Republic of Kazakhstan, 050040, Almaty, al-Farabi Ave., 71, al-Farabi KazNU;

Natalia Mikhailovna Kudro

Doctor of Social Sciences, Professor of Command and Control and Staff Duty Department of the Academy of Frontier Service of the Republic of Kazakhstan

\section{Larisa Abatolievna Biryuk}

Candidate of Educational Sciences, Associate Professor of Pedagogy and Psychology of the Higher Military School of the Academy of Frontier Service, addressee postal code: Republic of Kazakhstan, 050020, Almaty, Dostyk Ave., 103

Zhang Cao

1st Year Master's Student in "Pedagogics and Psychology" of the Department of Philosophy and Political Science of Al-Farabi Kazakh National University, Addressee Postal Code: Republic of Kazakhstan, 050040, Almaty, al-Farabi Ave., 71, al-Farabi KazNU

Doi:10.5901/mjss.2015.v6n6s1p380

\section{Abstract}

"The article analyzes the results of interdisciplinary research that includes exploration of similarities and differences in the systems of values of school students in two rapidly developing countries, which have identical problems and achievements in the field of education. The purpose of research is to determine the extent of collectivist and individualistic traits in the public consciousness of schoolchildren between the two countries, taking into account the influence of developmental trends of modern society and the system of general secondary education. Topicality of addressing the problem of increasing the level of spiritual development of young students is raised by a wide range of domestic and foreign experts. It often focuses attention on objective inevitability of channeling the work of school facilities towards practical activities of school teachers that in the eyes of young people restores traditional values that define the continuity of people's culture, play central part in shaping humanistic qualities of a person of the younger generation. The article highlights the main trends in the formation of the system of values of modern school students, their likes, and cultural preferences, indicating a ratio of individualist and collectivist culture features at a particular stage of development of society, the similarities and differences in the value consciousness of school students in the two countries. The authors support the idea of the development by modern school of a communitarian personality type that combines essential quality of individualist and collectivist culture".

Keywords: "Values of young people, system of value of school students, activities in the educational sphere, humanistic personality, value consciousness of an individual, communitarian personality type, individualist and collectivist type of culture".

\section{Introduction}

Values are commonly understood as a list of specific material, spiritual or natural objects that are of interest and the goal to achieve by individual or society. These are visions of individuals or groups of people of what is desirable, acceptable, good or bad. Differences in values are an important key to understanding the culture of a society and its further development. Systems of values are perceptions by which a person is guided in the world, determines his/her immediate 
and long-term goals in life and how to achieve them, having a selective approach to the set of values that specific culture offers. Methodological basis of the study of the system of values are built in the works of major representatives of foreign and domestic science: N. Machiavelli, K. Marx, Emile Durkheim, Berdyaev, E.Giddens, T. Parsons, A.S. Panarin, S.N. Ikonnikov, V.T Lisowski, A.A. Kozlov, Y. S. Kolesnikov, Abdyrayymov G.S. and others. In China, the problems of development of values and frames of reference of the youth were studied by Deng Xiaoping, Chen Yizi, Zhang Zemin, Zhang Weiming, Zhang Xiangguo and other scientists - researchers and practitioners. But no due emphasis is put on the analysis of the system of values of high school students, comparative mental analysis of perceptions of pupils from different educational systems, whose values must determine the construction of educational programs and plans, as well as mass cultural events. We should note immediately that social scientists offer different classifications and approaches to the study of values and systems of values in general, each of which has its own peculiarities, logic and value (Bayeva L.V., 2003). Thus, one of the founders of axiology Rickert offers division of values into six classes: logical (in academic achievements), aesthetic (in art), mystical (in worship), religious, moral, personal; philosopher and psychologist, $\mathrm{H}$. Münsterberg proposes distinguishing two types of values - life (eg., love, happiness) and cultural (eg., poetry, music); French axiologist, I. Gobry, highlights the main four values: usefulness, beauty, truth and goodness. American sociologist, $\mathrm{N}$. Smelser, identifying values as beliefs shared in a society (community) about the purposes which people should strive for, and main means to achieve them, divides them into two main categories: the terminal and instrumental (Smelser N., 1994). We could continue the list of methodological approaches and classification, proposed by scientists. But all researchers, regardless of the subject area, differences in classifications and approaches are united in the fact that eastern and western cultures have different systems of values. In Eastern culture, priority is given to the values of teamwork, unity of man and nature, man and society, respect for parents and elders, self-improvement attitude, changing oneself, and not the outside world. In Western culture first place is given to the values of individuality, career, business success, efficiency, competition and money. Thus, values perform overall strategic regulation of individual behavior in society, while systems of values of an individual characterize the tactical choice of his or her interaction with the environment. In this regard it seems important to find out how clearly social mind of the modern school student defines the features of collectivist and individualist culture. As a conscious regulator, which plays a motivational role and characterizes the moral choice of every individual, systems of values of young students allow to determine the scenario of the near future of any society, the possibility of adjusting the work not only of school facilities, but of all social institutions in order to enhance humanitarian component of their activities.

In our article we are going to adhere to the classification of values and methodological position of B. Erasov, who identified six major groups of values that, in our opinion, clearly establish the dominant ideas of value consciousness of a young person: 1) vital - life, health, safety and well-being; 2) social - family, discipline, hard work, entrepreneurship, wealth, equality and patriotism; 3) political - civil liberties, rule of law, constitution, peace and tolerance; 4) moral goodness, love, honor, decency, respect for elders; 5) religious - God, faith; 6) aesthetic - beauty, style and harmony.

Based on this, we will build a comparative analysis of systems of value of school students of the two countries who have great potential in rapprochement and mutually beneficial cooperation in many areas of social practice.

Study of systems of values of senior school students provides an important basis for improving socialization mechanism in the society as a whole. It was no accident that we decided in favor of studying students from graduating classes in China (PRC) and Kazakhstan (RK). The countries actively cooperate in many fields relevant for social growth and development. Over the long term there is a broad exchange of the students load, professional staff, and close cooperation in the economic field and provision of security in the world community. Study of the systems of values of young people is important for the future of the countries in terms of convergence on a common Eurasian economic space, developing relationship of the BRICS countries, closer cultural and educational cooperation and exchange of the resources between them. For the two countries the exchange of best practices is important in terms of creating an effective education system that does not only ensure high-quality training of professionals in the conditions of tough competition, but also an individual that preserves traditional values of its nation, ensuring stability and spiritual priorities for ultimate purposes.

A well-known British sociologist, Anthony Giddens, repeatedly drawn the attention of the world community to a significant transformation of values in many modern societies, increased aggression and proneness to conflict due to lack of proper cultural interaction and mutual influence that result not in a tendency to be isolated (localization), as it is at present, but to understand and convergence, which is inevitable in the context of globalization of the modern world. The scientist pays a lot of attention to comparative analysis of social processes in different cultures and communities, in the countries of the "core" of the modern world system and in the "second" and "third" worlds. He analyzes positive processes in the capitalist and socialist societies, as well as gaps in these world orders. The scientist attempts to find a compromise in determining future development of modern civilization (the Third Way). Naturally, the issue of forming a new type of 
person is determined, resulting from social search for a way out of spiritual crisis (Anthony Giddens, 1998).

Now it is time to pay more attention to the development of individual's sociability, their moral and spiritual purity, collectivist basis in modern society, understood as active involvement of each individual in addressing social problems. Leaders of China and Kazakhstan attach great importance to problems of development of the desired qualities and training of younger generation. For example, Kazakhstan's President, N. Nazarbayev, in Republic's long-term development program, "Kazakhstan Strategy - 2050" stressed: "What our country is going to be like in the future directly depends on what we are going to foster in our children today... Training of children is a huge investment in the future" (Address of the President of the Republic of Kazakhstan, the Leader of the Nation, Nursultan Nazarbayev to the people of Kazakhstan "Strategy" Kazakhstan-2050"). To educate means to deliberately teach socially important social behavioral skills and values. Secondary school, unlike higher education institutions, brings a person up by way of student team, its social, moral and psychological climate, creating mindset and guidelines through a "hidden agenda", forming collective qualities and mindsets that are sought-after in the culture of the social medium. This is the value of school education at a secondary level, during the period of active socialization of an individual, preparing for independent activity.

The moral of the Chinese people "is the fundamental measure of increasing basic qualities of the nation and is extremely important for the development of the national spirit, the formation of positive social and moral practices, promotion of harmonious development of material and spiritual culture and in the great task of comprehensive progress towards the building of socialism with Chinese specificity" (Bazarova A.N., 2009, p. 33). In this process, in contemporary China, secondary school plays a role of foundation of national culture through strict and consistent transfer of traditional principles that defend moral, unity of the nation in the preservation of morality as the basis of humanism.

Nowadays, all scientists agree that education is a process of deliberate and systematic development of a person in accordance with the cultural patterns that are in effect in the community and with a focus on their current and future state.

How is this process taking place now? We make an attempt to describe the effect of socialization process and of social environment on high school graduates between the two countries.

\section{Research Procedure: Survey, Qualitative Analysis of the Results}

Selection of Chinese school students was due to a combination of locations of Harbin and Gueydzhou schools in industrial centers. Gueydzhou School is a small provincial town in China. Sample group of schoolchildren in the Republic of Kazakhstan was determined by possibility to analyze values of school students from different educational environments of Almaty (as a developing industrial center) and suburban schools that can be called small country schools. Total of 186 Chinese students were surveyed, graduates of $12^{\text {th }}$ grades of higher secondary schools in the city of Harbin (school №24) - 58 respondents, Shenyang (School №27) - 65 students, Gueychzhou (school №2) - 63 students. Survey among Kazakhstani school children was carried out in 6 schools in Almaty (graduates of $11^{\text {th }}$ grades), Secondary School №132 - 30 students, Secondary School №68 - 30 respondents, secondary school №70 - 24 graduate, Haileybury private school, Almaty - 40 students, 15 public school of Ili Region (suburban schools) - 30 graduates, Belinsky secondary school, Almaty region - 30 respondents. Total - 184 students.

Hypothesis of the study: 1). Systems of values of Chinese school students primarily manifest features of collectivist culture that dominates, successfully competing with the values and norms of popular culture;

2). Sustainable presence of traits of a collectivist culture is largely due to enhanced component of humanitarian preparation of students;

3). In value consciousness of Kazakhstan's graduates, dominant position was taken by features of individualistic culture;

4). Traits of collectivist culture are strongly pronounced on individual values components that are associated with the great historical past of the nation.

\section{Research Results}

In our study we tried to define priorities when choosing the values for Chinese and Kazakhstani students. Despite the fact that Chinese and Kazakhstani students have differences in the educational process in terms of duration of training, number of students in classes, and some differences in the methodological and domestic aspects of teaching process support, through a learning process, school and education policy aims to preserve traditional values of the nation as the core of its spirituality and, at the same time, to be innovative following the time.

Comparative analysis of value consciousness of school students between the two countries has shown that lifepurpose values differ significantly (Table 1). There is a similarity in appreciating building a happy family. This gained most 
respondents in the two countries. Next in importance for respondents were such ultimate values as "doing something you love" - 20,23\% (PRC) and 24,46\% (Kazakhstan) and "making oneself useful in serving people" - respectively - 16,13\% and $17,03 \%$.

About equal desire to take "high position in society". Typically occurring was the absence of prevalent attention to acquiring riches and holding high status positions.

In Kazakhstani schoolchildren the desire to become a rich man is slightly more pronounced, while winning the respect of others is more pronounced in the opinion of Chinese school students (Table 1).

Table 1. "You do you see as the meaning of life?"

\begin{tabular}{|c|l|c|c|}
\hline$\Pi №$ & Options & Chinese School Students (in \%) & Kazakhstani School Students (in \%) \\
\hline 11 & Becoming rich & 8 & 10,98 \\
\hline 22 & Doing something you love (profession-wise) & $\mathbf{2 0 , 4 3}$ & $\mathbf{2 4 , 4 6}$ \\
\hline 33 & Building a happy family & $\mathbf{2 4 , 7 3}$ & $\mathbf{3 1 , 4 6}$ \\
\hline 44 & Making oneself useful in serving people & 16,13 & 17,03 \\
\hline 55 & Winning the respect of others & 17,74 & 8,15 \\
\hline 66 & Taking high position in society & 6,99 & 5,95 \\
\hline 77 & Other & $\begin{array}{l}\text { "building a better life" - (4,84), "вeк } \\
\text { живи, век yчись" - focus on life-long } \\
\text { learning (1,08) }\end{array}$ & $\begin{array}{l}\text { 1,9 - "fulfilling the dream of your family", } \\
\text { "creating my own talk-show", "communication } \\
\text { with people", "fellowship"; no answer - 4,17 }\end{array}$ \\
\hline
\end{tabular}

Let's look at some specific systems of values and ideals that are particularly attractive to school students.

Almost half of the Chinese schools' graduates (45,70\%) would like to be like the heroes of their national history, famous historical figures of their country. Moreover, students have named a lot of strong individuals of ancient China (Table 2).

Table 2. Responses of Chinese school students to the question "What historical figure or a contemporary known to all you would like to be like. Explain why did you choose him?"

\begin{tabular}{|c|l|l|c|}
\hline item/№ & Individual & Status in Chinese society & $\%$ choice \\
\hline 1 & Zhuangzi (V в. до н. э.) & Founder of Daoism philosophy & 2,15 \\
\hline 2 & Confucius (around. 551-479 B.C.) & Great Chinese thinker and philosopher & 4,84 \\
\hline 3 & Cao Cao (155 - 220) & $\begin{array}{l}\text { Chinese commander, author of works on military art and a poet; first minister of the } \\
\text { Han Dynasty }\end{array}$ & 2,15 \\
\hline 4 & Li Shimin (599-649) & $\begin{array}{l}\text { Emperor under the rule of Li Shimin, second emperor of Tang dynasty, ruled in 626- } \\
649 .\end{array}$ & 2,69 \\
\hline 5 & Kangxi (1662-1722) & Emperor from Qin Dynasty & 2,69 \\
\hline 6 & Wu Zetian (624-705) & The only empress in the history of China & 2,15 \\
\hline
\end{tabular}

Among well-known representatives of Western culture, science and art, Chinese school students have named such figures as Socrates (1,61\%), Newton (1,61\%); Einstein - 2,15\%, Shakespeare - 1,61\%, Van Gogh - 1,61\%; other $11,29 \%$. Among modern pop stars and sports ideals, the following were named as role models to follow: Taiwanese musician Zhou Jielong-2,15\%; TF Bous and EXO-M Music bands - 2,15\% respectively; actor Jackie Chan - 1,61\%, as well as sports stars (mainly domestic).

Well-known economists and entrepreneurs have also become role models: Ma Yun (Chinese businessman, founder of "Alibaba Group" - 3,76\%) Li Jiacheng, Li Ka-Shing (multi-billionaire, founder of Cheung Kong Holdings) 3,23\%, Brin (Last name) and Page (Last name) (the founders of Google) - 4,3\%, Bill Gates - 2,69\%, Steve Jobs - 3,76\%, other less publically known individuals $-13,44 \%$.

In general, politicians, scientists, generals, poets and artists as role models are presented in $45,70 \%$ of choice, contemporary sports and pop stars were named in $23,12 \%$ cases, business representatives - 17,74\%, others accounted for $13,44 \%$ of respondents' choice. There is hardly any explanation to the respondents' choices, one main one is that these people are known in the Western world, and particularly, their status (role) in the development of Chinese society.

Situation with Kazakhstani schoolchildren is somewhat different. The list of individuals worthy of respect and emulation, primarily includes politicians $(33,33 \%)$ and representatives of mainstream culture $(20,83 \%)$. Among political figures and military leaders were such figures as Margaret Thatcher, N. Nazarbayev (1,08\%); Putin - 1,08; Medvedev $0,54 \%$. From well-known individuals of the past the students named Leonardo da Vinci- 1,25\%, Alexander the Great 1.62\%; Napoleon, Che Guevara, Stalin - 0,54\% each, respectively. Among representatives of contemporary pop artists and movie stars they named J. Biber, M. Monro, A. Jolie, et al. Other choices $(45,84 \%)$ pointed to little-known figures in 
broad history, even characters of feature films or books (for example, Chingachgook, Sherlock Holmes).

Moreover, actors, singers and musicians collectively accounted for 16,67\%; parents - 3\%, athletes - 1, 67\%, writers - $11 \%$, historical figures $-14.79 \%$.

To which extent modern literature and cinema, who, as we know, play a very important role in the structuring of value priorities, take part in formation of value orientations.

Chinese school students are primarily interested in domestic publications: modern Chinese literature $(51,16 \%)$, works of representatives of ancient Chinese intellectual thought - 15.,9\%; $26,34 \%$ read foreign literature; $6,45 \%$ of respondents are interested in different types of art of declamation (legends, parables, etc.).

Kazakh students mostly read foreign literature $(50,84 \%)$. Of domestic publications $(20,83 \%)$ they prefer and know classic literature: works of A.S. Pushkin - 42\%, M.Y.Lermontov - 7\%, L.N. Tolstoy - 6\%, A.P. Chekhov - 3, 3\%, F.M. Dostoevsky - 2,5\%, Esenin - 7\%; among Kazakhstan's authors they named the works of the great Abai - 5\%, M. Mukataeva - 2,5\%, M. Zhumabayev - 2,5\%, I. Altynsarin - 2,92\%. From foreign authors Kazakhstani schoolchildren named: Omar Hayyam - 2.5\%, Murakami, Sparkas, Boris Akunin - 2,92\%, and others. "I do not read" - responded $15,83 \%$. The latter figure is frustrating when you think that not so long ago, Kazakhstan was one of the most reading countries in the world.

Thus, there are significant differences in the preferences of Chinese and Kazakhstani school students. Chinese school graduates prefer to read "their own", while kids in Kazakhstan prefer foreign literature.

In one of the studies conducted in eleven countries, the task was to analyze the impact of television on daily life; they compared activities of those who have a TV, and those who do not. The study was conducted in the United States, in a number of Western and Eastern European countries and in Peru. Respondents were asked to list all of their activities during 24 hours. In all countries, TV owners gave less time than others to hobnobbing, fellowship, household errands and sleep (Giddens E., 1999, p.317).

What is the impact of the media, particularly TV, on the outlook for almost a young adult? What is the range of interests of young people?

Kazakhstani schoolchildren are more interested in comedy and science fiction, which give a lot of positive thrills. In Chinese schools students are more prone to TV series, romance and action films. There is obvious impact on the tastes of common samples of popular culture.

Entertainment, music programs occupy central place in the selection of feature films and TV shows that both Chinese and Kazakhstani school students would prefer to see (Table 3,4).

Table 3. What type of feature films appeal to you the most?

\begin{tabular}{|c|l|c|c|}
\hline П№ & Options & Chinese schoolchildren (in \%) & Kazakhstani schoolchildren (in \%) \\
\hline 11 & Detective films & 9,68 & 10,74 \\
\hline 22 & Romance, TV Series & $\mathbf{1 8 , 8 2}$ & 17.65 \\
\hline 33 & Action films & $\mathbf{1 5 , 5 9}$ & 5,54 \\
\hline 44 & Science Fiction & 9,14 & $\mathbf{1 9}, \mathbf{9 1}$ \\
\hline 55 & Old movies & 4,84 & 3,02 \\
\hline 76 & Horror, thrillers & 8,60 & 11,44 \\
\hline 77 & Comedies & 6,45 & $\mathbf{2 3 , 9 2}$ \\
\hline 88 & Domestic films & 8,06 & 6,16 \\
\hline 99 & Other & "Anime" - 18,82 & "Anime"- $\mathbf{1 , 6 2}$ \\
\hline
\end{tabular}

Table 4. What TV programs do you prefer to watch when you have free time?

\begin{tabular}{|c|l|c|c|}
\hline П№ & Options & Chinese schoolchildren (in \%) & Kazakhstani schoolchildren (in \%) \\
\hline 11 & News, political programs & 20,43 & 20,71 \\
\hline 22 & Entertainment, music programs & 40,32 & 35,42 \\
\hline 33 & Feature films & 26,88 & 28,21 \\
\hline 44 & Educational programs & 12,37 & 14,5 \\
\hline 55 & Other & 0 & Don't watch any $-1,16$ \\
\hline
\end{tabular}

We note that school students are much less interested in news programs, socio-political programs that provide information of today and programs that develop intellectually. happy?"

For analysis of the respondents' personality they were asked the question: "What does a man need to feel 
For Chinese students it is, above all, a "good and strong family" (22,58\%), just as it is for Kazakhstani students $(58,1 \%)$. But after that the values differ. For Chinese graduate it is "a prestigious, well-paid job", for Kazakhstani students it is "confidence in the future" - $16,1 \%$. An interesting occupation that one enjoys is important for both categories of students: $19,81 \%$ (PRC); 9,7\% (PK). "Good conscience" is more important for Chinese students $(14,51 \%)$ than for Kazakhstani $(7,1 \%)$, as well as the belief that "you should always do what is right".

How strong is individualistic mindset in the behavioral culture in a social medium? Both Chinese and Kazakh graduates demonstrate obvious dominating desire "to stand out, to be a strong personality": $67,20 \%$ (PRC) and $70,5 \%$ (PK). The "being like everyone else is better and easier" mindset is much weaker: $32,80 \%$ and $29,5 \%$, respectively. It is no accident that $\mathrm{E}$. Giddens noted that in the midst of globalization there is a shift towards a new individualism that encourages people to express their own individuality (Anthony Giddens, 2005, p.64). We observe the presence of a "conflict of values" self -reliance - achievement - hedonism - kindness.

How well-developed are senses of social responsibility and patriotism in young people?

Most students are unanimous in their opinion that the statement "Think about your Motherland first and only then about yourself" is not always true: $36.55 \%$ (PRC); $40.1 \%$ (RK) (Table 5).

Table 5. What do you think about the following statement: "Think about your Motherland first and only then about yourself"?

\begin{tabular}{|c|l|c|c|}
\hline item/№ & Options & Chinese school students (in \%) & Kazakhstani school students (in \%) \\
\hline 11 & This corresponds to my life philosophy & 15,59 & 29,1 \\
\hline 22 & This statement is not always true & 36,55 & 40,1 \\
\hline 33 & This statement is outdated & 30,64 & 13,91 \\
\hline 44 & This does not comply with my views & 17,20 & 12,83 \\
\hline
\end{tabular}

Attitude towards action to protect the interests of the country also differ.

Which deed do students agree to perform in order to prove their loyalty to their Motherland? Chinese students gave the following answers: devotion to the Motherland is, first of all, "the knowledge of your national culture, history and traditions" $-65,05 \% ; 34,95 \%$ of respondents mentioned honoring national symbols of the country (flag, anthem, national emblem), of important milestones in the development of the country, knowledge of the natural environment in China, its resources, socio-demographic characteristics, basic processes occurring in the country, inter-ethnic problems, national traditions, knowledge of the laws of the country and performing your duties and exercise of granted rights.

For Kazakhstani school students patriotism are specific actions: "going to military service" - 13,44\%, "participation in military service", "if necessary - defending it" - 10,59\%, "to even die for your country; anything it takes"- 18,87\%; "to become a highly educated man" - 3,33\%; "make a significant contribution to the development of the country" - 10\%, "not a patriot" - 7,22\%; "no answer, and I do not know" - 36,55\%.

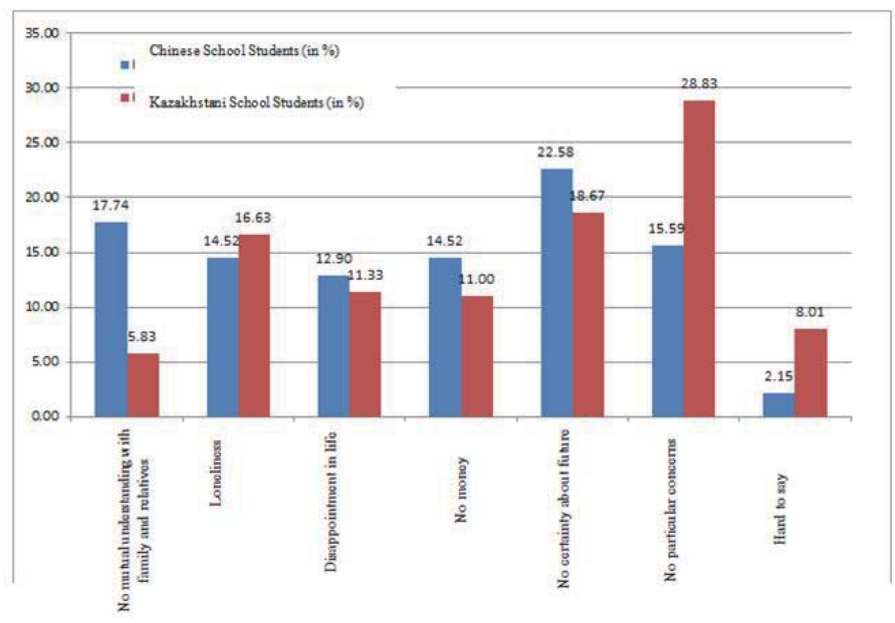

Figure 1. What are your major concerns today? 
For Chinese students, patriotism is respecting history, national symbols of the country, knowledge of its culture and lawabidance, while for Kazakhstani schoolchildren it is, above all, self-sacrifice, willingness to sacrifice their own interests for the good of the Motherland.

What do young people mean by patriotism? "Love of the country and of its people" - 47,31\%, "national pride" $44,09 \%$; "exercise of self-esteem" $-8,60 \%$. This is the opinion of Chinese school graduates.

School students of the two countries have much in common in understanding patriotism as a personality trait. $56,22 \%$ of school students of RK also understand this feeling as "love for the Motherland". "maintaining the honor and dignity of the status of the country" - 13,33\%, "being loyal to the Motherland, ability to defend the country, determination of the person" $-5,01 \%$. However, $25,44 \%$ of Kazakhstanis do not have a ready answer.

Penetration of individualism as a life stance becomes more obvious when a young man either does not think, or is not ready to think about the fate of society and his role in this process.

What are the greatest concerns of today's high school graduates today? You can trace it using a graphic image made based on the survey results (Figure 1).

Chinese school students are more concerned about "insecurity about the future" - 22,58\% (compared to $18,67 \%$ of survey respondents in Kazakhstan).

"No particular concerns", - said $28,83 \%$ of Kazakhstan's children. They feel a burden of "loneliness" - 16,63\%.

"Disappointment in life", as an attitude towards the existing reality in the very beginning of life is equally inherent in both categories of school students: $12,90 \%$ (PRC) and $11,33 \%$ (SC).

Which social institutions could take on a supporting function amid moral choice? Are religious beliefs a social tool that affects the behavior of an individual student? We asked respondents a series of questions that were meant to identify their feelings about religion, philosophy, atheistic orientation or piety. What role, in the opinion of respondents, does it play in social life? (Figure 2).

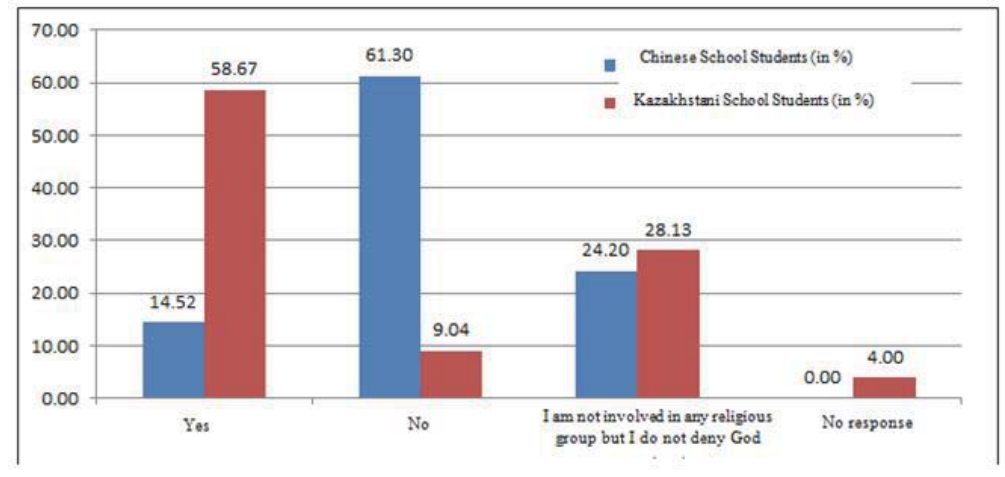

Figure 2. Are you religious?

The survey demonstrated that the majority of Chinese respondents rely primarily on themselves and are atheists, unlike Kazakhstani respondents (Figure 2). The unity of opinion is observed when it comes to the belief that each person needs to believe in something, no matter what religious beliefs they hold. School students believe that in the name of morality and protection of morals, religion can act effectively as a socializing factor. Answering the question "Does a person need to believe in God?", 46,24\% of students from China responded "Do not know", 23,12\% - "Probably does because each person needs to believe in something", "I think they do, because it stops people from doing evil"- $12,37 \%$, "They do, because it makes a person better"- $13,44 \%$; "It is not necessary, because it enslaves him, depriving of freedom" - only $4,84 \%$. Summarizing the responses of Chinese respondents we should note that most of them primarily reply on themselves.

A completely different picture is seen in the views of Kazakhstani students, most of whom believed that religion should perform an important role as a social mechanism in regulating relations between people (Figure 3). 


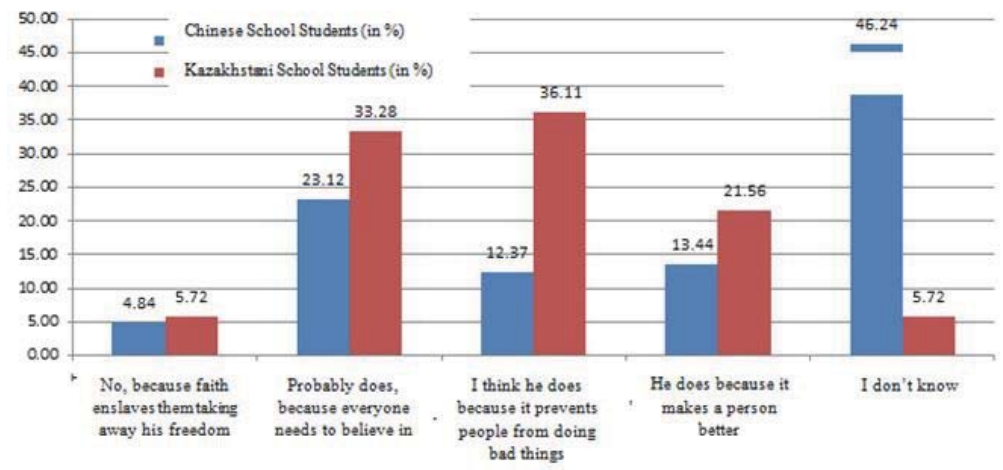

Figure 3. Do you believe that a man needs to believe in God?

Chinese school students are less critical in how they see the reforms and changes happening in their country. Answering the question: "How would you describe the transformation taking place in your country?" most of them - 41,94\% - said "need to work more, then we will succeed" (versus 23,13\% in schoolchildren of Kazakhstan), "These changes are for the better" - 32,06\% (versus 10,25\% of Kazakhstani students). 16,13\% of Chinese students and 25\% of students from RK found it difficult to assess.

Answering the question: "If you knew for sure that nobody would ever know about what you did, would you be able to break the law?" - The majority of Chinese students responded negatively - 58,60\%; Kazakhstani students were less definite: only $20,79 \%$ of them said "no". As is known, culture includes the values carried by members of a specific group, standards that govern daily activities of individuals. Standards represent "do's" and "don'ts" of social life. To what extent are young people willing to cross the line of what is permitted, in a way characterizes the culture of society as a whole.

\section{Discussion}

Traditional values, cultivated for centuries and supported by public institutions, are an important and always relevant component of the content of school education, a constraining factor in the spread of destructive forms of thinking and behavioral mindsets of a person living in an unstable world subject to cultural threats.

Person's education and culture are the most important status characteristics of a modern Chinese; they have become a kind of "religion", the basis of personal culture, therefore the culture of modern China has been subjected to attacks of mass culture, immorality of market psychology, and generally is withstanding the onslaught of aggression, unpredictability and risk as a consequence of globalization processes.

For centuries China has cultivated respect for moral values, every citizen must strictly adhere to obligatory principles: caring for minors, respect for elders, duty, sincerity and honesty, which are considered to ensure peace and harmony in society. These human qualities are traditionally valued above all else and are top priority in the public consciousness. Process of learning in the Chinese high schools is built on these principles. The most important goal of education in China is nurturing in the students of juizi highly moral qualities, which refers to the ideal embodied in the image of a noble man. It is in the process of learning, Confucius thought, that man becomes better and more ethical and seeks to remedy shortcomings and unworthy acts. Therefore, moral upbringing and development of ethical standards since olden times occupied a priority position in the Chinese education system and represents its strong "trump card".

Chinese teachers actively redefine the experience and ideas of advanced foreign educational systems and schools. The effects of pedagogical reforms in other countries, updated content of their own education, forms and methods of training, rapidly improving technology of educational activities, combining the effectiveness of training and business and moral components in the development of a person. The country successfully applies advanced innovative techniques that have almost been forgotten, or are not widely used in the homeland of their creators. An example is the education system of V.F.Shatalov that allows to, while saving precious years develop a love of knowledge and learning throughout life, and trains a person not for any narrow area of professional field in the future (Volokhova E.A., Yunkina I.V., 2004, p. 241-242).

In China since ancient times, high status of educators has been thoughtfully maintained. Since 1993, a special law 
on teachers was adopted, which established the rights and responsibilities of teachers, requirements for their employment and their social guarantees. During the period of reforms in the country, teachers' salaries increased by an average of 15 times and exceeded 31 thousand Yuan (4840 dollars) per year and 15 thousand yuan (2340 dollars) for teachers of primary and secondary schools. As a result, China has become the country with the world's largest body of teachers (Fu Xiao Xia, 2000, p.93), which, incidentally, is comprised of the best scientific forces of the world.

Thus, the government of the country and its leadership constantly improve the mechanism of interaction between the government, the public, family and educational institution, developing a favorable social climate that promotes continuous improvement of the educational system, which also provides the opportunity to learn at any age. This practice is used for training teachers in Kazakhstan.

Collectivist type of culture, inherent in educational system of both China and Kazakhstan, is subjected to thorough "attacks" of individualism and mass culture, but is not destroyed. The hypotheses delivered by the authors have been confirmed in the course of the study. But in Kazakhstani schoolchildren individualism as life stance is more pronounced.

So, we see that today's younger generation of China has an awareness of the importance of cultural values of the country, its history, moral ideals, but there is a significant influence of "Westernization" in terms of tastes and preferences when there is equal choice - "for myself" or "not only for myself". Tradition, knowledge of which is provided by an in-depth study of history, literature, art of one's people, respect for all periods of its development, since ancient times, is a kind of talisman of morality and social responsibility of Chinese school students, it is a spirituality talisman.

Cotemporary Kazakhstan researchers observe significant value difference between older and the present-day generation . The regularity of social environment succession has been abused, the notion of Motherland lost its essential content, devaluated (Abdikakimov M.T., 2014, p.66-67)

Value scales of priority choice made by the Kazakhstan schoolchildren frequently tends towards material factors in prejudice of spiritual and moral ones. One of the real options to restore the balance adopting experience of China is a profound study of the history of the nation and human civilization in general without limitation to teaching applicative disciplines at educational institutions. Fundamentality of young person's preparation for life shall be, first of all, provided by non-fragmentary but integral study of human history, the role of each nation in its development. Only in this case the personality harmonically combining positive traits of collectivist and individualist culture, communitarian type of personality, supported by A. Etzioni (Gritsanov A.A., et al., 2003, p. 1280-1281) may be formed, the basis of lawgoverned and social state as a human ideal may be provided.

Scientists predicting further development of human society, make very different predictions about the individualization of its members. Some of them believe that future belongs to the spirit of individualism and individualistic culture (F. von Hayek, K. Popper), while others relate the increasing individualism to degradation of human kind (V.I. Vernadsky, P. Teilhard de Chardin), advocating for convergence of positive social mechanisms that regulate social and global problems of mankind as a whole. Such an integrated approach, in our opinion, is the most acceptable as a compromise, and taking into account cultural characteristics and needs of all the peoples who are interested in peace and stability. The system of ethical coordinates and spirituality also determines the search for the desired scenario of the development of educational systems all over the world. Empirical studies in the world have shown that pure individualism and collectivism are rather rare. In every culture there are evidences of both. But their relationship varies considerably, as we saw in our study. Eurasian countries, such as, for example, Kazakhstan, now increasingly begin to show traits of individualistic culture, in which, by the way, participates the credit system of education as the Western approach to acquiring and using of knowledge.

At the same time, right now there is a search at the highest, political level, for ways to improve educational system that preserves traditional spiritual values through intensification and technologization of educational services, ensuring continuity of methodology and educational culture. According to research by $F$. Trompenaars in societies with high individualism, interests of an individual (personal happiness, achievement and well-being) are put above the interests of the group. And at the same time, in any situation a person will first take care of his own interests and the welfare of his own family. Social values are losing their relevance.

With the predominance of collectivist cultures, on the contrary, the interests of a group take precedence over individual interests. Individual members of society are responsible for ensuring that their actions work for the benefit of the whole society. Here the significance of a man is determined by how he/she serves the interests of the community. Values that are important to him are social order, respect for tradition, family security and communicative wisdom. In this regard, researchers even identify countries dominated by individualistic values and collectivist values, and therefore dominated by such type of culture. This is evidenced by studies of G. Hofstede (Hofstede G., 1994) and F. Trompenaars. Among countries with a preference for individualistic values (where more than $50 \%$ of respondents chose the first option of the proposed dilemma "if you have as much freedom as possible and maximum opportunities to develop yourself, it will 
result in improvement of the quality of life", or "if individual continuously cares about his comrades, it will improve the quality of life for everyone, even if it makes it difficult to manifest individual freedom and individual development") European countries are absolutely predominant (Trompenaars F., 1996).

Individualism as a personal quality, according to the results of the comparative study conducted by us, is more frequently manifested in Kazakhstani school graduates.

\section{Conclusion}

Today, the task of school education in any country should be the task of forming a communitarian type of personality who has (cannot but have noospheric mentality) and in the goal-setting is not only guided by utilitarian values, but also by value priorities traditionally inherent in Eurasian and Asian nations. It is important, by providing opportunities for selfrealization through "vaccination" of subjectness of individualism, to bring together in a young person the best qualities of traditional culture (mutual aid, social responsibility, honor, love, and family). Positive individualist and collectivist qualities in a modern person are intended to harmoniously unite, transforming a school student into a person actively working and exploring his own reserves and abilities for the improvement of social medium and personal growth through cooperation and tolerance.

We know that the foundation of individualism inherent in Western culture, are built into human consciousness of Western culture from early childhood. And first of all, pragmatic values (benefit as a dominant idea of interaction, while the task of a family as a social institution in this case is to "putting a child on his/her feet" and to teach him/her to live independently (Bellah R.N., et al., 1988).

Once this goal is reached, it is expected that the child will leave the family and begin to live on his/her own (Kim U., et al., 1994).

Contact with parents and close relatives can be minimized or even cease, which breaks the continuity of generations and the law of development of any culture. The trouble is that sometimes individualists resist society, believing that the interests of a single person can go against public interests, while in social and constitutional state as an ideal of the future things must be exactly the opposite.

The position of cultivation of individualism in a family reduces its role as the primary agent of socialization, in the emerging personality devoid of systematic psychological support of the nearest and dearest can easily develop a sense of loneliness and meaninglessness of existence. When describing themselves, such a category of young people emphasize the primacy of self-centeredness as a philosophy of life.

The values of individualism are dominant in the "golden billion" developed countries, but are much less pronounced in other countries, where most of contemporary human race live (Schwartz S. H., 1995). The task of modern states, not included in this "golden list" is to form their own flow path to the perfect man and society. Harmonious combination of the best traits of individualism and collectivism in a personality of today's young person, as the foundation of future society is another step towards a better understanding and cooperation between countries in addressing global problems of mankind as a whole.

Interestingly, the ratio of traits of collectivism and individualism in values and systems of values may vary. This is due to the social situation, social environment and policies of a certain state. For example, studies conducted in the mid1990s by All-Russian Public Opinion Research Center have shown that $58 \%$ of Russian respondents did not approve of those who are trying to go beyond the group, while only $20 \%$ believe that one should be guided by the views of the majority, and $56 \%$ are in favor of independent decision-making. But in the early 2000 s, according to the Russian sociologist, M.K. Gorshkov, the share of supporters of individualistic values (25-30\% of Russia's population) remained below the share of adherents of collectivism (35-40\%) (Latov Y. V., 2001). This was greatly influenced by socio-economic condition of the society, the collapse of the former system of education and cultural and educational work.

In countries with a predominance of collectivist ideology (typical example is China) social networks are built on different principles. People here put achieving the goals of the group to which they belong at the heart of everything. If needed, they are ready to sacrifice their own interests. Public consciousness in a collectivist culture suggests that the wealth of individual citizens of the country can in no way compensate for the poverty of society as a whole. Chinese school students work hard for society and its prosperity. China's experience of society development shows skillful combination of collectivist culture traits and individualistic spirit; it demonstrates that the tradition combined with collectivist culture mobilize to achievements by controlling moral corridors of achieving goals, quite effectively.

It should be noted that the experience of countries that had absolute success in education in the past and at the present time is also actively studied in the Republic of Kazakhstan. In this respect, contacts in the field of education between the universities of Russia and Kazakhstan develop naturally. Mental characteristics of cultures of the Russian 
Federation and Kazakhstan as the former Soviet countries have many similarities; there is a high degree of similarity in value characteristics of the youth of the two countries (Latova N.V, 2007, pp. 94-95), which allows to quickly attract a wide strata of innovation without destroying traditional values. Equally carefully engaging European experience and ideas (as is done in Russia), and maintaining ancestral values of collectivism, Kazakhstan is also looking for its own version of the optimal functioning of educational institutions as institutions of cultural reproduction, bearing in mind that the "rational side" - individual educational ideas, may be borrowed but in practice they are creatively processed and refracted in the spirit of the nation ((Ushinsky K.D., 1948, 33).

"Mangilik El" strategic concept of society development of the President of Kazakhstan, Nazarbayev, implies unity of the people on the basis of shared spiritual and moral values which are the source of Kazakh national spirit. President emphasizes the importance of cultural core for every nation in the modern world (Tugzhanov E., 2015). The President calls the introduction of "Mangilik El" values into existing curricula of school education to be one of the concrete steps to implement the reforms (Nazarbaev N., 2015)., p.3).

Each country should have its own experience in forming an innovative component of education that links training and education with the life of society and production needs. No country can distance itself from the objective tendencies to address world's problems, in particular, educational ones. However, as shows the experience of China's modernization, only by adhering to the principle of ethnic and cultural conformity. In this respect, cooperation between People's Republic of China, Russian Federation and Kazakhstan in the sphere of education must be more closely linked to the mutual interests of the BRICS countries, focused to a greater extent on collectivist culture. The main purpose of education and socialization in Western culture is only primary socialization that goes against traditions of the Eastern and Eurasian communities where educational institutions are actively involved in the formation of personal qualities in all subsequent stages of socialization; it is difficult to depart from the norms of morality here under the pretext of limitation of personal freedom of choice.

Therefore the most important tasks of schooling as the middle level of socialization of a young person is implementation of the principle of humanism through the maintenance of cultural conformity in the preparation of educational programs; upbringing of a person through the wide humanitarian preparation through basic textbooks that reflect their humanistic focus and interest, both to their own and to the world's history, articulating clear goals and moral modes in the process of formation of the personality. In this regard there needs to be established a steady systematic exchange of experience in the use of new technologies that support the integrity and consistency of acquired knowledge generating sustainable moral, humanistic positions in life, guiding young people towards moral choices. Specific features of the proposed model are another subject, but one that, in our opinion, should be the result of concerted efforts of the Eurasian states.

\section{References}

Abdikakimov M.T. Intergenerational differences in values (case study) (according to the results of sociological research). // Bulletin of Al Farabi Kazakh National University.- \# 2 (49) .- 2014.- pp.63-69.

Address of the President of the Republic of Kazakhstan, the Leader of the Nation, Nursultan Nazarbayev to the people of Kazakhstan "Strategy" Kazakhstan-2050"- new political course of the established state" - Astana: Ak Orda, 2012.- [electronic resource] Access Mode. -URL: Http://ru.government.kz/site/news/2012/12/65.

Anthony Giddens Sociology/ With participation of K. Birdsall: Trans. from English. 2nd Ed. completely revised. and add. M.: Editorial URSS, 2005.- p. 632.

Anthony Giddens The Third Way: The Renewal of Social Democracy, Cambridge: Polity, 1998 - pp.166.

Bayeva L.V. Value bases of individual existence: Existential Axiology Experience: Monograph. M.: Prometheus. Moscow State Pedagogical University. 2003.- p. 240.

Bazarova A.N. Confucian values and moral education in China's education system // Bulletin of the Buryat State University. - $2009 .-$ \# 8. -p. 33-35.

Bellah R.N., Madsen R., Sullivan W.M., Swidler A. \& Tipton, S.M. Individualism and commitment in American life: Readings on the themes of habits of the heart. New York: Harper \& Row, 1988.

Fu Xiao Xia. Main directions of modern school education reforma in China: Dis. ... Cand. ped. sciences: 13.00.01: SPb., 2000.- p. 172.

Giddens E. Sociolfy.- M .: Editorial URSS, 1999.- p. 704.

Hofstede G. Cultures and Organizations (Software of the Mind). Harper Collins Publishers, 1994; Hofstede G., et. al. measurement of organizational culture: qualitative and quantitative study of twenty cases // Administrative Science Quarterly. 1990 Volume 35.

Kim U., Triandis HC., Kagitcibasi C., Choi S.-C., \& Yoon G. Individualism and collectivism: Theory, method, and applications. Newbury Park, CA: Sage, 1994.

Latov Y. V., Latova N.V. Russian Economic Mentality in the World Context. - Social Sciences and Modern Era. 2001, № 4; Danilova E., Tararuhina M. Russian industrial culture in G. Hofstede parameters. -Monitoring of public opinion. 2003, No. 3 (65). 
Latova N.V, Latov Y.V. Special aspects of "Westernization" of the students mentality in modernizing countries// Sociological Research. 2007.- \# 11.- p.90-98.

N. Nazarbaev. Plan of the Nation- 100 steps. The modern state for everyone // Kazakhstanskaya Pravda, May 20 (\# 92), $2015 .-$ p.1-5.

Schwartz S. H. Individualism-collectivism. Critique and proposed refinements. Journal of Cross-Cultural Psychology \#21, 1995. P. 139157.

Smelser N. Sociology: translated from English.- M : Phoenix, 1994.- p.688.

Sociology: Encyclopedia / compiled by A.A. Gritsanov, V.L.Abushenko, GM Evelkin, et al., M.: Book House, 2003, p. 1312; Etzioni A. A Responsive society. San Francisco, 1991;

Trompenaars F.Resolving International Conflict: Culture and Business Strategy // London Business School. 1996. Vol. 7 (3); Trompenaars F., Hampden-Turner Ch. When Two Worlds Collide // Intercultural Management Consulting, 2000.

Tugzhanov E. "Mangilik El": one country, one destiny // Kazakhstanskaya Pravda, May 1 (\# 81), 2015.- p.8.

Ushinsky K.D. Collected Works. - M.; L.: APN., 1948. - V. 3 - p. 692.

Volokhova E.A., Yunkina I.V., Didactics, Rostov-on-Don, "Phoenix", 2004. 